\title{
Efficacy of Thermophilic Soil-Isolated Paenibacillus sp. NBR10 as a Chitinolytic and Biocontrol Bacterium-In vitro Study
}

\author{
Mohamed H. El-Sayed ${ }^{(1,2)}$, Olfat M. Nassar ${ }^{(3)}$, Heba A. Nasr ${ }^{(1)}$, Abd El-Nasser A. \\ Kobisi ${ }^{(4) \#}$ \\ (1)Department of Biology, Faculty of Science and Arts, Northern Border University, \\ Kingdom of Saudi Arabia; (2)Department of Botany and Microbiology, Faculty of \\ Science (Boys), Al-Azhar University, Cairo, Egypt; ${ }^{(3)}$ Department of Home Economics \\ (Nutrition), Faculty of Science and Arts, Northern Border University, Kingdom of \\ Saudi Arabia; (4)Plant Protection Department, Desert Research Center, El-Mataria, \\ Cairo, Egypt.
}

\begin{abstract}
MONG microbial enzymes, chitinases received increased attentions due to their wide applications especially in agriculture sector for biocontrol of fungal phytopathogens. The growing interest in chitinases with thermostability nature, forced many researchers to isolate and characterize novel chitinase producing-bacteriafrom extreme environments. The present study describe characterization of thermostable chitinase produced by thermophilic soilisolated bacterial strain NBR10 from Rafha governorate, Saudi Arabia. Chitinase producing NBR10 strain was identified as Paenibacillus sp. according to the traditional methods of morphological, biochemical and physiological characteristics coupling with sequencing of $16 \mathrm{~S}$ rRNA(GenBank accession number KT957624.1). The isolated strain was found to have a potent antifungal against three of the phytopathogenic fungi Fusarium oxysporum, Alternaria burnsii and Rhizoctonia solani with percent of growth inhibition 52.575 .0 and $85.71 \%$, respectively. Chitinase obtained from Paenibacillus sp. NBR10 showed activity at ranges of temperature $\left(30-90^{\circ} \mathrm{C}\right)$ and $\mathrm{pH}(4-9)$, showing optimum activity at $55^{\circ} \mathrm{C}$ and $\mathrm{pH} 7.0$, respectively. Also, it exhibited high thermostability at higher temperatures, where $90 \%$ of its activity is retained at $65^{\circ} \mathrm{C}$ for $36 \mathrm{~h}$. The promising chitinolytic and antifungal activity of locally isolated Paenibacillus sp. NBR10, candidate this strain to be used as a potential biological control agent.
\end{abstract}

Keywords: Soil, Paenibacillus sp. NBR10, Thermostable chitinase, Antifungal, Biological control.

\section{Introduction}

Every year thousands of tons of biowastes are generated globally (Pachapur et al., 2016). Persistence and accumulation of these wastes cause environmental issues (Kim et al., 2007). After cellulose, chitin considers the second abundant polysaccharide found in nature (GarciaFraga et al., 2015). Chitin is found in many sources in nature such as fungal cell walls, shells of crustaceans, exoskeleton of arthropods and eggs of nematodes (Brzezinska et al., 2014) and in midgut of many invertebrates (Hegedus et al., 2009).

Chitin has not been applied to large-scale industrial use because of its extreme insolubility
(Jeraj et al., 2006). Breaking down of chitincontaining wastes into oligosaccharides has attracted great attention because the useful biological activities of these oligosaccharides such as antifungal, antitumor, and immunity enhancement activities (Dai et al., 2011).

Chitin is a polysaccharide with linear structure formed of N-acetyl-Dglucosamine (NAG) residueslinked with $\beta-1-4$ bonds (Zarei et al., 2012), and hydrolyzed by diverse chitinolytic enzymes with different modes of hydrolysis. These enzymes can be classified as endochitinases, exochitinases, chitobiases, and $\beta-\mathrm{N}$-acetylglucosa minidases(Brzezinska et al., 2014).

Chitinases are produced by different

"Corresponding author email: nasrkobisi77@yahoo.com

DOI: 10.21608/ejbo.2018.4698.1194

Edited by: Prof. Dr. Wael S. El-Sayed, Faculty of Science, Ain Shams University, Cairo, Egypt.

(C)2019 National Information and Documentation Center (NIDOC) 
microorganisms such as bacteria, fungi and algae and are involved in various biological processes as defense against pathogens, nutrition and morphogenesis (Yan \& Fong, 2015). Commercially chitinolytic enzymes are used to produce NAG and chitooligosaccharides as part of pharmaceutical formulations. Purified chitinase enzyme has been used to generate protoplasts from yeasts and fungi and to deter the growth of pathogenic fungi, treatment of chitinous wastes (Dahiya et al., 2006).

In the recent decades, bacterial chitinases received over attention because of their promising applications, especially in agriculture sector as abiocontrol agent against harmful phytopathogenic fungi and insects, because of their containing of chitin components. Moreover, chitinases form bacteriaact as a potent alternative biopesticides for the chemical fungicides (Singh, 2010 and Yong et al., 2017).

Chitinases are produced by many Paenibacillus spp. (Savita et al., 2013; Itoh et al., 2014; Ruth et al., 2016; Xiaoxiao et al., 2017 and Yong et al., 2017). Paenibacillus are known to have a biocontrol activity which due to their ability to producevariety of enzymes of degrading the plant cell wall, e.g. chitinases, cellulases, proteases and $\beta$-1,3-glucanases (Budi et al., 2000). Microbial chitinase are formulated as commercial biocontrol antifungal agents due to their ability to hydrolyze the cell walls of fungal pathogens (Flach et al., 1992 and Kim et al., 2008, 2010, 2011). Chitinase is part of the biological control agents (Chet et al., 1990 and Lorito et al., 1994) produced by isolates of Bacillus spp. (Chang et al., 2003; Lee et al., 2009 and Reyes-Ramirez et al., 2004), Paenibacillus spp. (Savita et al., 2013 and Itoh et al., 2014).

Although many studies mentioned isolation and characterization of Paenibacillus species with chitinolytic activity from different environments; hot spring soils (Hui et al., 2011), seafoods (Singh, 2010) and marine (Patel et al., 2007). A few numbersof studied focused on thermophilic bacteria having chitinolytic activities (Manucharova et al., 2011).

In recent years, thermostable chitinases received increased attention, because of their applicable properties in various industrial processes which performed at high temperatures
(Kuzu et al., 2012). Soil microorganisms, especially thermophilic species have the ability to produce chitinolytic enzymes with thermostable nature (Manucharova et al., 2011).

Because of the various applications of chitinases, obtaining a novel chitinolytic bacterial strains with unique extreme properties is of great concern. Desert soils are harboring microorganisms growing at a broad temperature range. Therefore, the present study aims to isolate and characterize bacterial strains with thermostable chitinolytic activity from desert soils of Rafha governorate. Further, the physicochemical properties of the produced chitinase from this strain and its antifungal activity against some fungal hytopathogens were also determined.

\section{Materials and Methods}

\section{Materials}

Chitin (crab shell) and $\rho$-nitorphenyl-Nacetylglucosamine were purchased from SigmaAldrich Chemical Co. (St. Louis. MO, USA). All other chemicals used were of analytical grade purchased from either Sigma or Merck Chemical Co. (KGaA, Darmstadt, Germany).

\section{Sampling}

Ten soil samples were collected from the upper $5-15 \mathrm{~cm}$ depth around wild plants; Horwoodia dicksoniae \& Rumex cyprius from desert of Rafha governorate at the Northern Border region in Kingdom of Saudi Arabia. The collected samples were taken in clean plastic bags, until further proceedings, samples were stored in the refrigerator at $4^{\circ} \mathrm{C}$.

\section{Preparation of colloidal chitin}

Colloidal chitin was prepared according to an established method of Chandrasekaran et al. (2012), $5 \mathrm{~g}$ of chitin powder was added slowly to $100 \mathrm{ml}$ of concentrated $\mathrm{HCl}$ with vigorous stirring on ice overnight. Then, the mixture was added dropwise to $1 \mathrm{~L}$ of ice-cold ethanol with rapid stirring for $4 \mathrm{~h}$. Finally, the precipitate was collected by suction filtration and washed with water until the washing solution was neutral. The colloidal chitin was stored at $4^{\circ} \mathrm{C}$ for subsequent use.

Selective isolation of chitinase-producing bacteria For isolation of chitinase-producing bacterial 
strains, $5.0 \mathrm{~g}$ soil were added to $100 \mathrm{ml}$ saline $(0.85 \%)$ and shaken vigorously for $1 \mathrm{~h}$. Serial dilutions were made and spread onto colloidal chitin agar (CCA) media containing (w/v): $0.5 \%$ colloidal chitin, $0.7 \%\left(\mathrm{NH}_{4}\right)_{2} \mathrm{SO}_{4}, 0.1 \% \mathrm{~K}_{2} \mathrm{HPO}_{4}$, $0.1 \% \mathrm{NaCl}, 0.01 \% \mathrm{MgSO}_{4} \cdot 7 \mathrm{H}_{2} \mathrm{O}, 0.05 \%$ yeast extract, $0.1 \%$ bacto tryptone and $2.0 \%$ agar at $\mathrm{pH}$ 7.0 (Yuli et al., 2004). The plates were incubated at $50^{\circ} \mathrm{C}$ for 7 days, and colonies showing clear halos were selected. Colonies exhibiting different morphological appearances were picked individually and further purified by subculturing on the same medium. Once purified, each isolate was processed to find out its chitin solubilizing (CS) ability in CC medium. This was done by calculating the zone of clearance to colony size (Faramarzi et al., 2009). Isolates were stored as a glycerol stock at $-80^{\circ} \mathrm{C}$. Among these strains, one designated as NBR10 exhibited high CS and was selected for further investigations.

\section{Taxonomic studies of chitinase-producing NBR10} strain

Morphological, physiological and biochemical characterization

Morphological and physiological characterization of the isolate was performed according to the Bergey's Manual of Systematic Bacteriology(Williams etal., 1989). Morphological characteristics such as colony morphology and cell morphology of the selected bacterial strain were studied (Holt et al., 1994). For biochemical characterization, different biochemical tests were studied by the test kit of api ${ }^{\circledR} 20 \mathrm{E}$ and api ${ }^{\circledR} 50$ CHB Medium, bioMérieux, Marcy-I'Etoile, France. The results were analyzed with the APILAB Plus software (Logan \& Berkeleym, 1984 and Fundagül et al., 2009). The test of api was carried out at Bacteriology Laboratory, the Holding Company for Biological Products and Vaccines (VACSERA), El-Dokki, Giza, Egypt. The biochemical tests were constructed according to methods described by Sneath (1984).

\section{Molecular characterization}

DNA isolation and amplification of $16 S \mathrm{rRNA}$ gene: A single, pure colony of the isolate was taken from the plate grown culture and was suspended in $10 \mu 1 \mathrm{TE}$ buffer [10mM Tris (pH 8.0), 1 m MEDTA]. The samples were mixed briefly using cyclo mixer, and $5.0 \mu \mathrm{l}$ of this suspension was applied to FTA ${ }^{\circledR}$ Classic Card (Whatman International Ltd.) and allowed to dry for at least $1 \mathrm{~h}$ at room temperature. Further processing of the sample was done according to the manufacturer's instructions. The 16S rRNA genes were amplified using forward (5'-GAGTTTGATCCTGGCTCAG-3') and reverse (5'-AGAAAGGAGGTATCCAGCC') primers (Xcelris Labs Ltd., India) known to be conserved among all known bacteria (Ulrike et al., 1989). PCR was performed in an automated thermal cycler (PTC-200, M J Research Inc.) with an initial $92^{\circ} \mathrm{C}$ denaturation for $2 \mathrm{~min} 10 \mathrm{sec}$; followed by 35 cycles of $92^{\circ} \mathrm{C}$ for $1 \mathrm{~min} 10 \mathrm{sec}, 48^{\circ} \mathrm{C}$ for $30 \mathrm{sec}$, $72^{\circ} \mathrm{C}$ for $2 \mathrm{~min} 10 \mathrm{sec}$ and a final extension at $72^{\circ} \mathrm{C}$ for $6 \mathrm{~min} 10 \mathrm{sec}$ (Massol-Deya et al., 1995). The PCR products were resolved by electrophoresis on $1.5 \%$ agarose gel (BioRad, Hercules, CA) and visualized using gel documentation system (UVIpro, UVItec).DNA isolation and purification, 16S rRNA gene amplification and sequencing was carried out at Clinilab Company, El-Maadi, Cairo, Egypt.

Phylogenetic analysis: The partial sequences obtained from isolated strain was initially compared with reference sequences by using BLAST (National Centre for Biotechnology Information at www.ncbi.nlm.gov/BLAST) to determine their phylogenetic affiliations. The sequences were manually checked and submitted to Ribosomal Database Project (RDP at http:// rdp.cme.msu.edu/) and the most closely related phylotype was identified. The sequences were finally aligned in the alignment explorer tool of the MEGA 4 software (Tamura et al., 2007) with the alignment parameters set to default values, and the phylogeny reconstruction analysis was performed with the help of the Neighbour joining method.

Nucleotide sequence accession number: The partial 16S rRNA gene sequence determined for chitinase-producing bacterial strain NBR10, identified as Paenibacillus sp., was deposited in the GenBank under accession number KT957624.1.

\section{In-vitro antifungal activity}

The antifungal activity of the strain NBR10 was investigated against three important fungal phytopathogens, Alternaria burnsii, Fusarium oxysporum and Rhizoctonia solani, under in vitro conditions using a dual culture technique (Faramarzi et al., 2009). These phytopathogens were supplied from Plant Protection Department, Desert Research Centre, Cairo, Egypt and maintained on potato dextrose agar (PDA, Merck Co.) medium. 
The antifungal activity of the isolate NBR10 was determined on yeast malt extract agar (YMEA) medium by perpendicular streak method (Wadetwar \& Patil, 2013). Isolated bacterial strain was cross streaked as a single line on solidified YMEA media in a petridishs and incubated at $28^{\circ} \mathrm{C}$ for $72 \mathrm{~h}$. The fungal test organisms were then cross streaked perpendicular to the original streak of isolates. Control plates of the same medium without bacterial growth were also simultaneously streaked with test organism to study their normal growth.

\section{Chitinase production}

Chitinase production by the isolate NBR10 was performed at $50^{\circ} \mathrm{C}$ in $250 \mathrm{ml}$ Erlenmeyer flasks containing $50 \mathrm{ml} \mathrm{CC}$ medium $(\mathrm{pH} 7.0)$ at 180rpm for 7 days, and the enzyme production was monitored at every $24 \mathrm{~h}$.

\section{Assay of chitinase activity}

The chitinase activity was determined colorimetrically by detecting the amount of $\mathrm{N}$-acetyl-D-glucosamine (NAG) released from a colloidal chitin substrate (Vyas \& Deshpande, 1989). A 48h grown culture was harvested and centrifuged in a microfuge (Biofuse Primo-R) at $10,000 \mathrm{rpm}$ for $10 \mathrm{~min}$ to obtain cell-free culture supernatant. The reaction mixture $(1.0 \mathrm{ml})$ for enzyme assay consisted of enzyme $(340 \mu \mathrm{l})$ with CC $(3 \mathrm{mg})$ as a substrate in $50 \mathrm{mM}$ sodium acetate buffer $(\mathrm{pH} 5.0)$. This mixture was incubated at $55^{\circ} \mathrm{C}$ for $1 \mathrm{~h}$; the remaining colloidal chitin of the reaction was removed by centrifugation at $10,000 \mathrm{rpm}$ for $10 \mathrm{~min}$, and the chitinase activity was assayed in the supernatant by measuring the released sugar from colloidal chitin (Nelson, 1944). Briefly, the above supernatant was reacted with dinitrosalicylic acid (DNS) by boiling for $5 \mathrm{~min}$ and absorbance of the released NAG was measured in reaction mixture at $540 \mathrm{~nm}$ after cooling to room temperature. One international unit (IU) was defined as the activity that produced $1 \mu \mathrm{mol}$ of the product per hour.

\section{Physico-chemical characterization of enzyme}

Chitinase activity was measured in crude culture supernatant of isolate NBR10 at various $\mathrm{pH}$ values (3.0-10.0) using the following buffers (50mM): sodium acetate buffer ( $\mathrm{pH} 3.0-6.0)$, sodium phosphate buffer $(\mathrm{pH} 7.0)$, Tris- $\mathrm{HCl}$ buffer ( $\mathrm{pH} 8.0-9.0)$ and glycine- $\mathrm{NaOH}$ buffer ( $\mathrm{pH}$ 10.0); temperature ranged from 20 to $100^{\circ} \mathrm{C}$.
The thermal stability was determined by initially preincubating enzyme at various temperatures $\left(20-100^{\circ} \mathrm{C}\right)$ for different time intervals $(0-44 \mathrm{~h})$ in a dry bath. After the heat treatment, samples were cooled and assayed for residual enzyme activity.

\section{Statistical analysis}

All the optimization studies were conducted in triplicate and the data were analyzed using single factor analysis of variance (ANOVA). All the data are graphically presented as the mean \pm S.D. of triplicates $(n=3)$. ANOVA was performed using Microsoft Excel 2007.

\section{$\underline{\text { Results and Discussion }}$}

Isolation and screening for chitinase producing bacteria

Isolation of bacterial strains capable of producing chitinase with a novel property such as stability for a long time at high range of temperature, have been the focus of recent research. In this study, an attempt has been made to characterize thermos-stable chitinase enzyme produced by the soil-isolated bacterial strain. Eleven bacterial cultures were isolated from different soil samples collected from different localities from desert of Rafha governorate at the Northern Border region in Kingdom of Saudi Arabia. The obtained bacterial isolates were screened qualitatively for chitinase production under thermal $\left(50^{\circ} \mathrm{C}\right)$ conditions using colloidal chitin agar (CCA) medium. Faramarzi et al. (2009) reported that, the qualitative assay of chitinase was performed by measuring the clear zone around the colony.

Out of 11 isolates, $3(27.2 \%)$ isolates were found to be chitinase positive through appearance of clear zone on the CC agar medium. Among them, strain NBR10 which isolated from soil sample from rhizosphere of wild plant, being the highest chitinase producer (Fig. 1). This isolate was selected for production of the enzyme in the fermentation medium. Soil rhizosphere contains many hydrolytic enzymes which included in recycling of nutrients, maintaining of soil fertility, decomposition of organic residues. The extracellular enzymes produced by rhizospheric microorganisms play initial role in degradation of high molecular weight polymers such as cellulose, pectin, lignin and chitin (Geetha et al., 2014). 


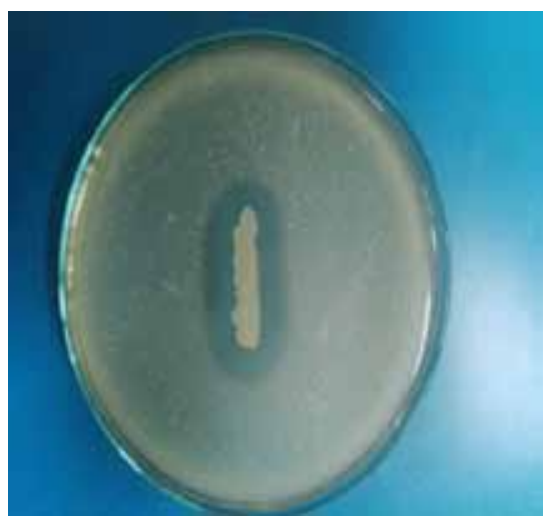

Fig. 1. Qualitative screening of NBR10 isolate for chitinolytic activity on CCA medium.

Characterization of selected chitinolytic strain Morphological, physiological and biochemical characterization

On the basis of morphology,isolate NBR10 showed morphological features typical for the genus Paenibacillus. The macroscopical investigation of colonies grown on nutrient agar plates showed smooth, translucent, convex and creamy coloured colonies. The microscopical examination showed small rod-shaped Grampositive cells (Fig. 2).

The biochemical and physiological characteristics of this isolate NBR10 are recorded in Table 1. It was found that the isolate was able to grow at $\mathrm{pH}$ values between 5 and 10 with optimum $\mathrm{pH} 8$ and in the presence of 2-6\% of $\mathrm{NaCl}$. The maximum growth temperature was recorded at $50^{\circ} \mathrm{C}$, while the limiting growth was observed at $60^{\circ} \mathrm{C}$. Also, the isolate was positive for amylase, caseinase, lipase and catalase enzymes. The results of biochemical and physiological characteristics of the isolate
NBR10 recorded in Table 1 are analyzed with the APILAB Plus software. Our identification results are compared with data in Bergey's Manual of Systematic Bacteriology (Sneath, 1984) and Bergey's Manual of Determinative Bacteriology (Holt et al., 1994) of the genus Paenibacillus.

The morphological, biochemical and physiological identification of the isolate NBR10 was confirmed with sequencing of $16 \mathrm{~S}$ rRNA which ensured relatedness of this isolate to the family Paenibacillaceae. The phylogentic analysis of sequence of NBR10 was performed and phylogenetic tree is constructed (Fig. 3) with 98\% similarity to Paenibacillus thailandensis S3-4A (NR_041490.1) hence our isolate is coded as Paenibacillus sp. NBR10. Ash et al. (1993) genus Paenibacillus includes facultative anaerobic, endospore-forming, Gram-positive bacterium previously was classified as Bacillus while in the recent time it classified as a separate genus.

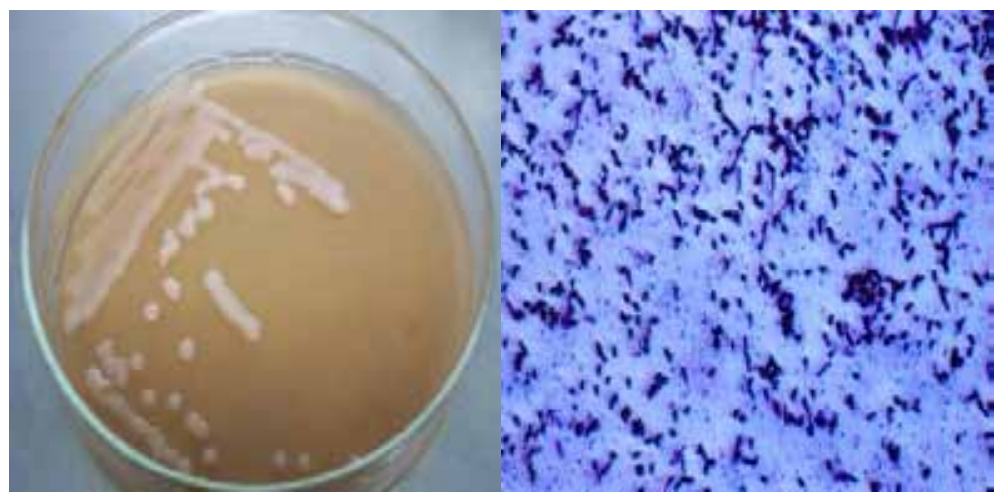

(a)

(b)

Fig. 2. Morphology of the isolate NBR10; (a) Culture characteristics (grown on nutrient agar media), (b) Rod shaped Gram-positive cells (light microscope X1000). 
TABLE 1. Biochemical and physiological results of isolate NBR10 isolate.

\begin{tabular}{|c|c|c|c|}
\hline Characteristic & NBR10 & Characteristic & NBR10 \\
\hline Control & - & Glycogen & + \\
\hline Starch & - & Erythritol & - \\
\hline Gentiobiose & - & D-arabinose & + \\
\hline Xylitol & - & Glycerol & - \\
\hline D-lyxose & + & L-arabinose & + \\
\hline D -turanose & - & D-xylose & + \\
\hline $\mathrm{D}$-fucose & - & D-ribose & + \\
\hline D-tagatose & - & D-adonitol & - \\
\hline D -arabitol & + & L-xylose & + \\
\hline $\mathrm{L}-$ fucose & - & D-galactose & + \\
\hline Gluconate & + & Methyl- $\beta$ D-Xylopyranoside & - \\
\hline Fructose & + & $\mathrm{L}$-arabitol & + \\
\hline D-glucose & + & 5-keto-gluconate & - \\
\hline L-sorbose & - & 2-keto-gluconate & - \\
\hline D-mannose & - & Arginine dihydrolase & - \\
\hline Dulcitol & - & Beta-galactosidase & + \\
\hline Ornithine decarboxylase & + & L-rhamnose & + \\
\hline Lysine decarboxylase & - & D-mannitol & + \\
\hline Hydrogen sulfide & - & Inositol & - \\
\hline Citrate & + & Methyl- ${ }^{\mathrm{D} D}$-Mannopyranoside & - \\
\hline Trytophane deaminase & + & D-sorbitol & - \\
\hline Urease & + & Amygdalin & + \\
\hline Indole & - & Methyl-a D-Glucopyranoside & - \\
\hline $\mathrm{N}$-acetylglucosamine & - & Gelatinase & + \\
\hline Esculin & + & VP & + \\
\hline Arbutin & - & O-F test & oxidation \\
\hline D-cellobiose & + & Nitrate reduction & + \\
\hline Salicin & + & Caseinase & + \\
\hline D-lactose (bovine origin) & + & Catalase & + \\
\hline D-maltose & + & Lipase & + \\
\hline D-saccharose (sucrose) & + & Nuclease & - \\
\hline D-melibiose & + & Amylase & + \\
\hline Inulin & - & Range of growth & \\
\hline D-trehalose & + & $\mathrm{NaCl} 2-6 \%(\mathrm{w} / \mathrm{v})$ & + \\
\hline D-raffinose & + & Temperature $20-60^{\circ} \mathrm{C}$ & + \\
\hline D-melezitose & - & pH 7-10 & + \\
\hline
\end{tabular}

+= Positive, $-=$ Negative 


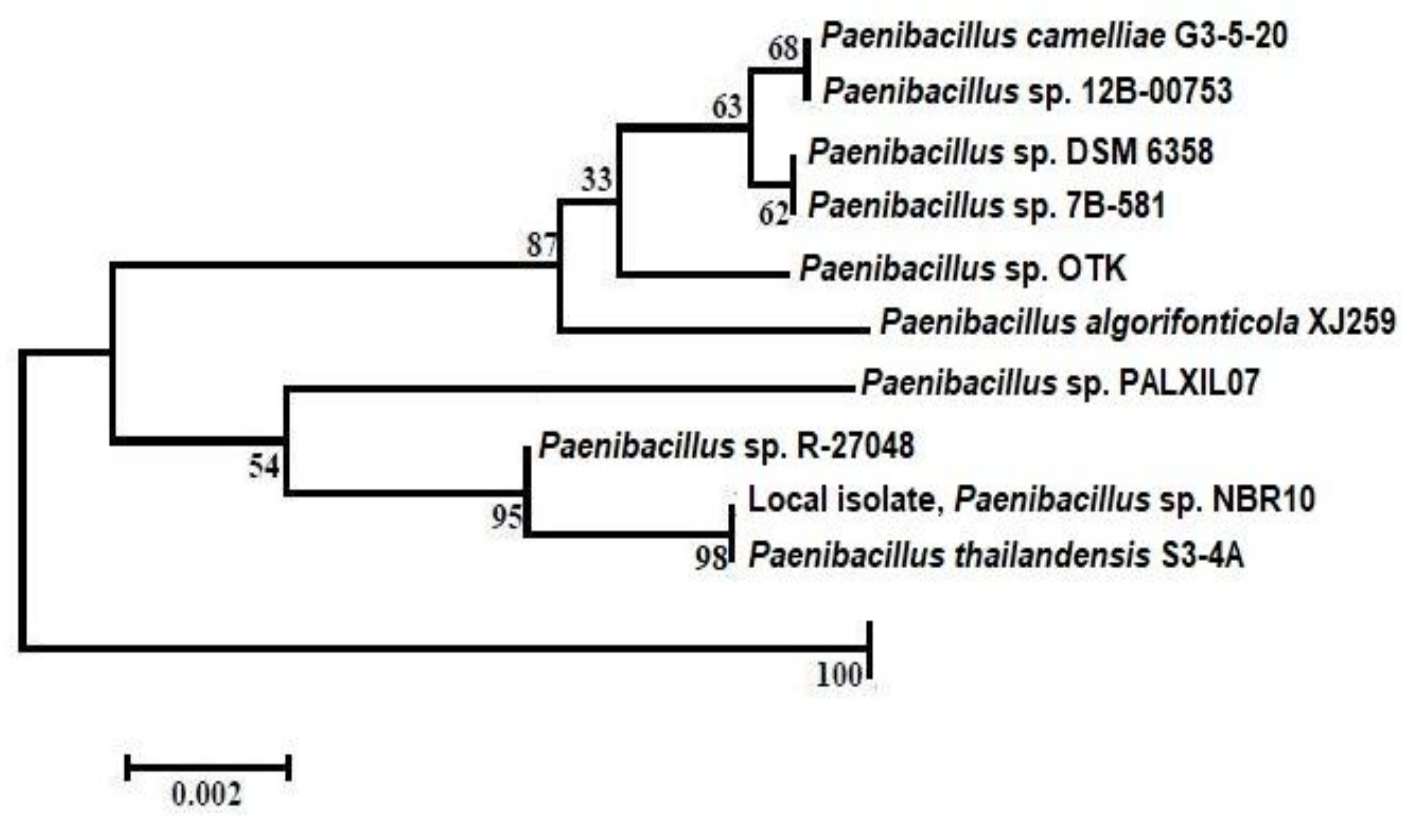

Fig. 3. Sequencing of 16S rRNA gene and phylogenetic analysis of Paenibacillus sp. NBR10 strain.

Antifungal activity of Paenibacillus sp. NBR10

The local NBR10 isolate exhibited antifungal activity against 3 of phytopathogenic fungi with percent of growth inhibition arranged as 52.5\% against Fusarium oxysporum, $75.0 \%$ against Alternaria burnsiiand $85.71 \%$ against Rhizoctonia solani (Fig. 4) which indicate possibility of using of this strain as a biocontrol agent against fungal phytopathogens. Paenibacillus sp. BISR-047 exhibited similar growth inhibition against various phytopathogenic fungi: F. oxysporum and A. burnsii (Savita et al., 2013). Many species of Paenibacillus can be act as antagonists for plant pathogens, such as nematodes, bacteria and fungi (Bloemberg \& Lugtenberg, 2001; Sheng et al., 2014 and Natalija \& Dzoko, 2018).

Production of chitinase from Paenibacillus sp. NBR10

Impact of different incubation periods on production chitinase was investigated From 1 to 8 days at $50^{\circ} \mathrm{C}$. The enzyme activity was recorded after $1^{\text {st }}$ day of incubation, the maximum activity $(2.71 \pm 0.076 \mathrm{U} / \mathrm{ml})$ was observed at $5^{\text {th }}$ day (Fig. 5). Singh (2010) reported that, production of chitinase is proportional with concentration of chitin in the medium where after complete utilization of chitin results in decreasing in the chitinase activity. Many studies discussed the impact of incubation period on chitinase yield in different Paenibacillus species. Ruth et al.
(2016) reported the incubation time required to reach the maximum enzyme level of chitinase production from the Paenibacillus sp. D3 was at $24 \mathrm{~h}$ of incubation whereas, Singh (2010) reported the optimum incubation period for chitinase production from Paenibacillus sp. D1 was at $72 \mathrm{~h}$ while it was 6 days for Paenibacillus sp. BISR047 (Savita et al., 2013).

Effect of different temperatures on chitinase production

The incubation temperature incredibly influences microbial development rate, catalyst secretion, catalyst restraint, also protein denaturation (Kunamneni et al., 2005), the obtained chitinase showed high activity at a broad range of incubation temperature $20-60^{\circ} \mathrm{C}$ with optimum activity $(2.91 \pm 0.152 \mathrm{U} / \mathrm{ml})$ at $55^{\circ} \mathrm{C}$. A strong decrease in the chitinase activity $(2.15 \pm 0.132 \mathrm{U} / \mathrm{ml})$ was recorded with increasing of temperature at $60^{\circ} \mathrm{C}$ (Fig. 6). Different studies focused on effect of temperature on chitinase production by Paenibacillus species and reported activity of these enzymes at different ranges. Singh (2010) reported activity of chitinase production by Paenibacillus sp. D1 at temperature range $30-60^{\circ} \mathrm{C}$ with optimum $50^{\circ} \mathrm{C}$, whereas, Savita et al. (2013) reported that, chitinase production by Paenibacillus sp. BISR-047 was recorded at temperature range $28-65^{\circ} \mathrm{C}$ with optimum temperature $45^{\circ} \mathrm{C}$. 


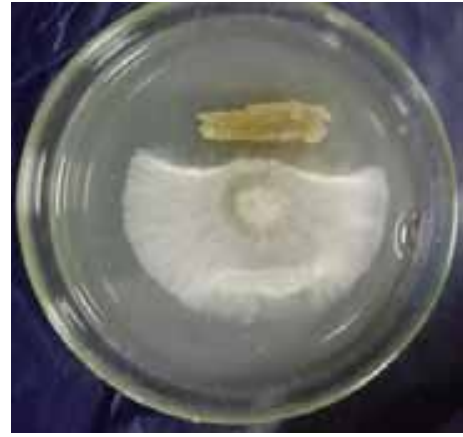

(a)

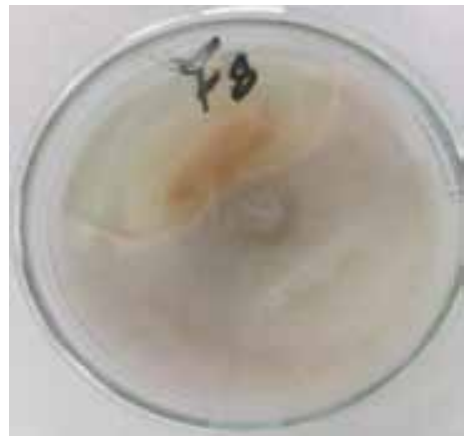

(b)

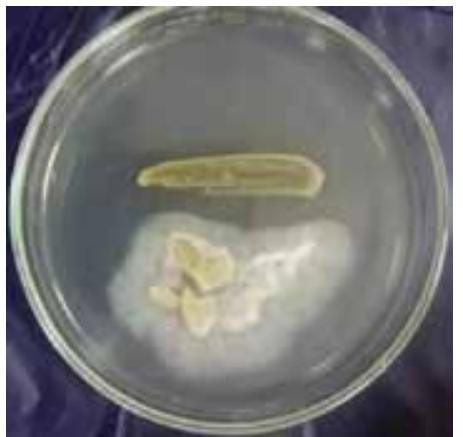

(c)

Fig. 4. Antifungal activity of Paenibacillus sp. NBR10 against: (a) Alternaria burnsii, (b) Rhizoctonia solani and (c) Fusarium oxysporum.

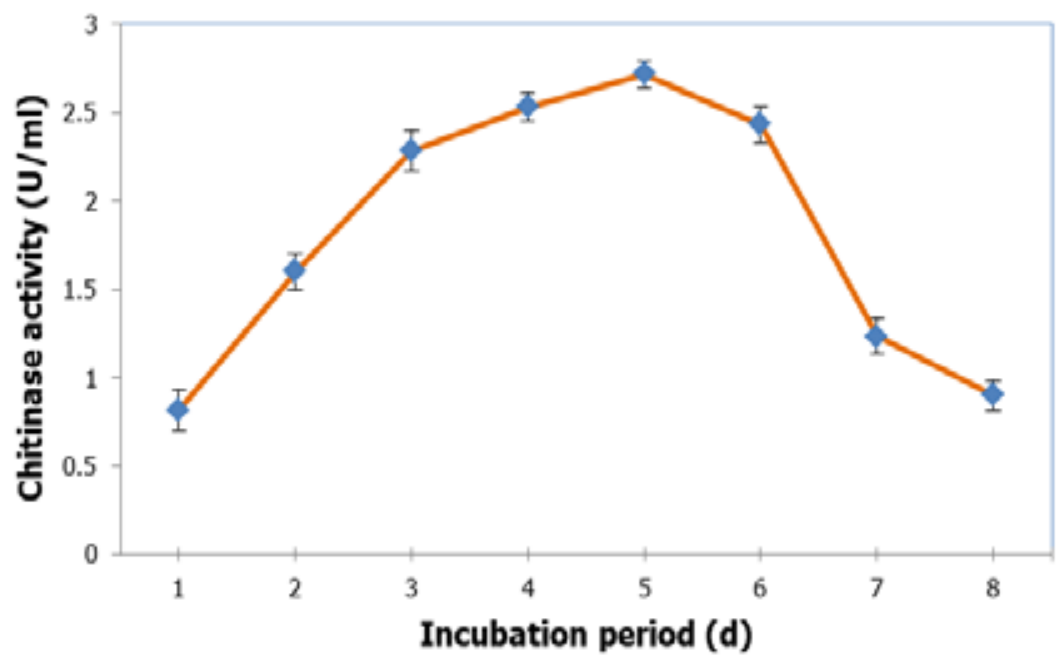

Fig. 5. Production of chitinase at different incubation period.

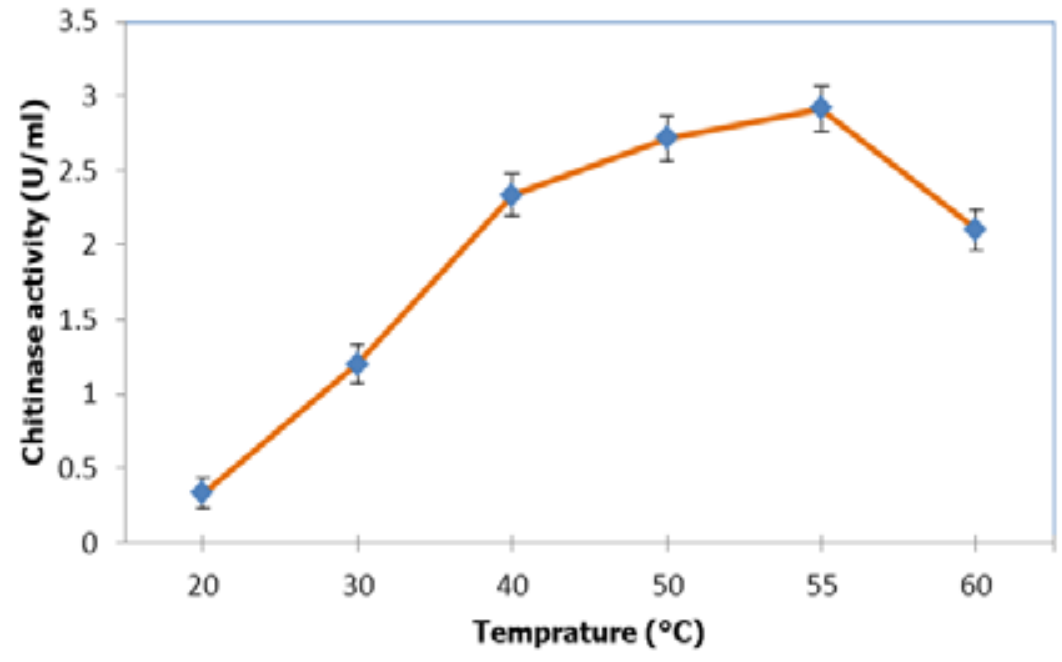

Fig. 6. Production of chitinase under different incubation temperatures.

Egypt. J. Bot. 59, No.1 (2019) 
In our study Paenibacillus sp. NBR10 which was found to grow at temperatures upto $60^{\circ} \mathrm{C}$, but did not show any growth above $65^{\circ} \mathrm{C}$, whereas its crude chitinase showed activity up to $55^{\circ} \mathrm{C}$. This shows that the enzyme produced by thermophilic bacterial strain NBR10 is highly thermophilic in nature. The area selected for the present study has been characterized by complex dune physiography with alkaline soil $\mathrm{pH}$ and extremely low organic carbon content (Gothwal et al., 2007). In these areas, soil temperature crosses $50^{\circ} \mathrm{C}$ in the summers and this can be correlated with the growth temperature of the isolated strain.

Effect of different $p H$ values on chitinase production

$\mathrm{pH}$ is one of the most important factors influences the enzyme activity where the balance of the microbial metabolite depend on concentration of the hydrogen ion (Kunamneni et al., 2005). In this study, production of chitinase was recorded at $\mathrm{pH}$ range $3.0-8.0$, with the maximum activity $2.63 \pm 0.104 \mathrm{U} / \mathrm{ml}$ at $\mathrm{pH} 7.0$ (Fig. 7). Several workers have reported broad range of $\mathrm{pH}$ optima for chitinase, from 4.0 to 10.0 for Paenibacillus pasadenensis CS0611 (Xiaoxiao et al., 2017), 4.0 to 10.0 for Paenibacillus thermoaerophilus TC222b (Ueda \& Kurosawa, 2015), from 3.0 to 9.0 for Paenibacillus barengoltzii (Fu et al., 2016).

Effect of temperature and time on stability of chitinase

Effect of thermal conditions on chitinase activity produced by Paenibacillus sp. NBR 10 was studied through incubationthe enzyme in $50 \mathrm{mM}$ sodium acetate buffer ( $\mathrm{pH}$ 7.0) at temperatures ranged from 20 to $100^{\circ} \mathrm{C}$ for $1 \mathrm{~h}$. The activity of the enzyme was determined at the range $30-90^{\circ} \mathrm{C}$ where the enzyme retains with more than $50 \%$ of its activity at this range. The activity of chitinase was increased gradually with increasing the temperature up to $60^{\circ} \mathrm{C}$. The maximum activity was obtained when temperature increased to $65^{\circ} \mathrm{C}$. But it showed slight decrease in its activity with the increasing in temperature at $70^{\circ} \mathrm{C}$ (Fig. 8). These results ensure the thermal nature of the produced enzyme.

The produced chitinase was found to be stable when incubated for period of time ranged from 0 to $36 \mathrm{~h}$ in $\mathrm{pH} 7.0$ and $65^{\circ} \mathrm{C}$, where no change in chitinase activity was observed when the enzyme incubated in these conditions (Fig. 9). Although the enzyme activity decreased when incubation time increased for more than $36 \mathrm{~h}, 59 \%$ of original enzyme activity was retained. The obtained results ensured stability of chitinase enzyme produced by Paenibacillus sp. NBR10 in thermal conditions for a long period of time. Similar results have been reported for many works of Paenibacillus species such as Paenibacillus sp. (Singh, 2010), Paenibacillus sp. BISR-047 (Savita et al., 2013), Paenibacillus barengoltzii (Fu et al., 2016).

Most of the industrial processes which depend on enzymatic reactions are performed at high temperatures, thus in the last few years, researches focusing on thermostable enzymes has been increased. As we know, there is no previous reports on isolation and characterization of thermostable chitinase by Paenibacillus sp. from the Northern Border region, in Saudi Arabia.

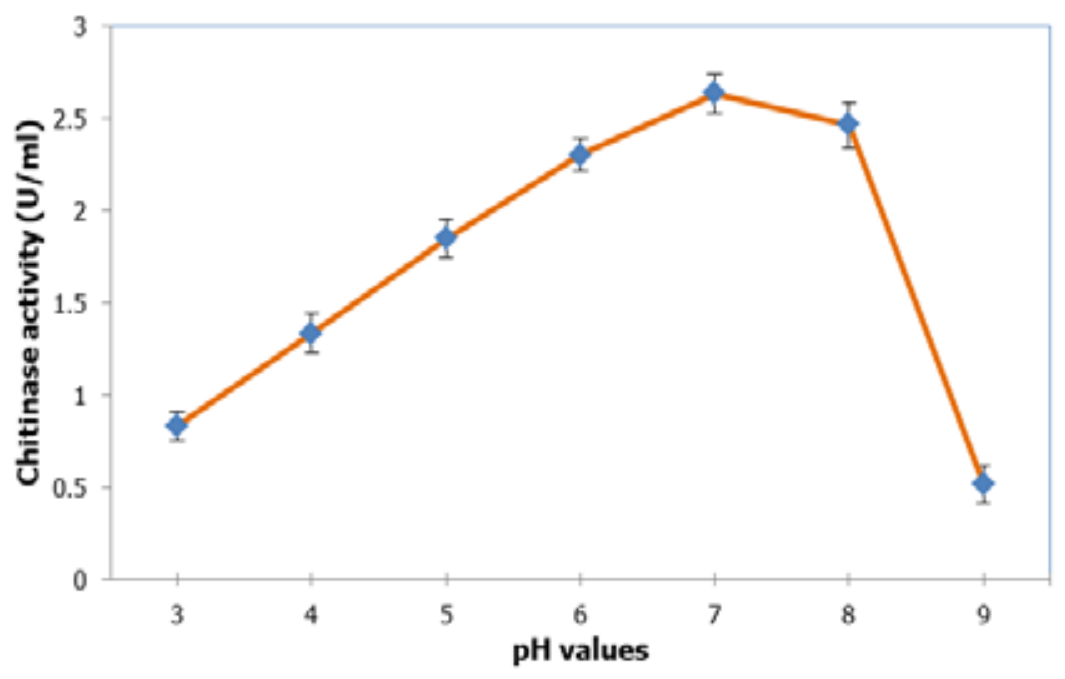

Fig. 7. Production of chitinase at different values of $\mathrm{pH}$. 


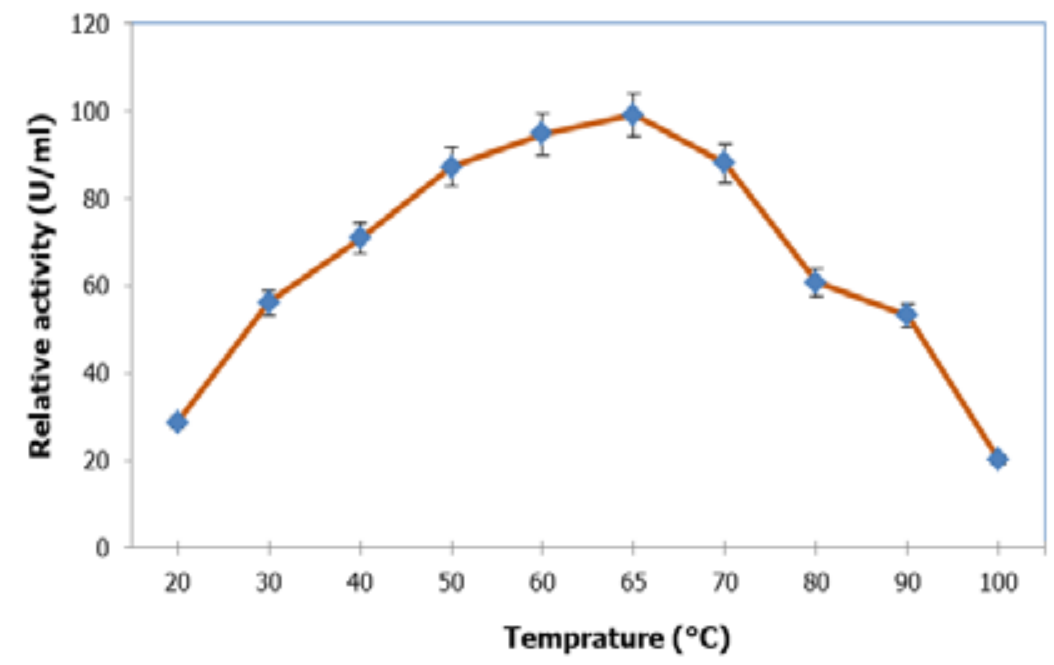

Fig. 8. Thermal stability of chitinase at different temperatures.

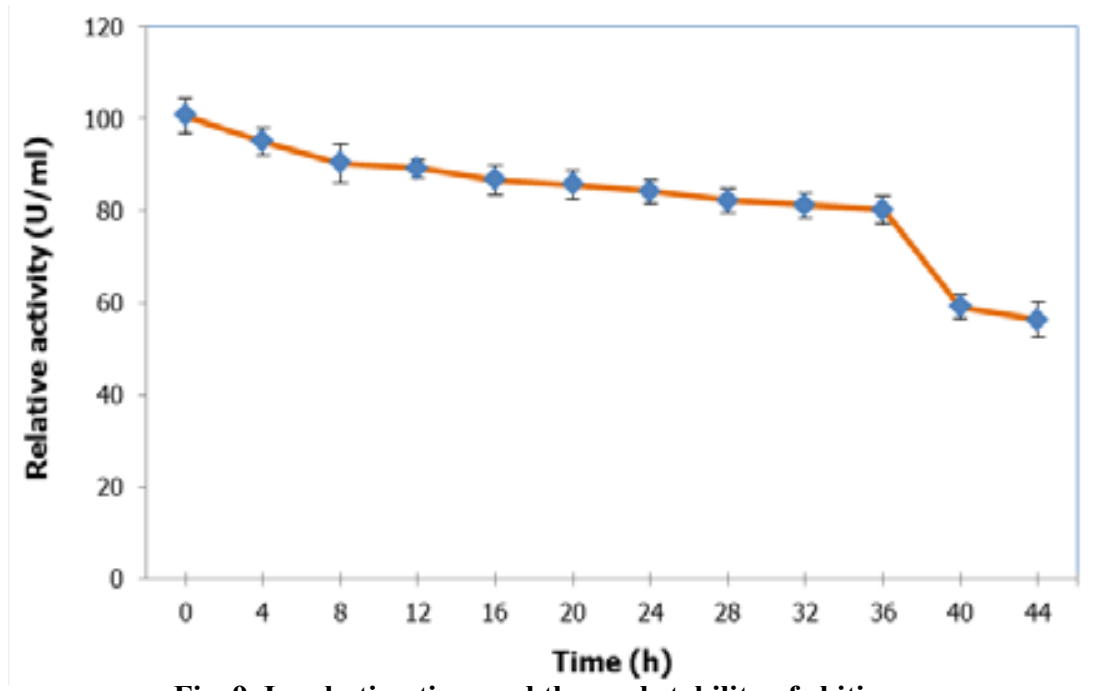

Fig. 9. Incubation time and thermal stability of chitinase.

\section{Conclusion}

Conventionally, fungicides used to control damage caused by fungal phytopathogens contribute several environmental problems as degradation, pollution, lethal effect on beneficial rhizobacteria and development of resistant strains. Thus, there is a great need for alternate strategies for controlling the fungal diseases. Thermotolerant chitinaseproducing bacteria offers a potential alternate and additive to toxic chemical fungicides in reducing their dosage in agriculture. Our results conclude, the locally isolated Paenibacillus sp. NBR10 isolate exhibited unique properties of potent inhibition of phytopathogenic fungi and high chitinase production. Hence to confirm these properties especially under field conditions further in vivo studies are required.
Acknowledgement: Mohamed H. El-Sayed, Olfat M. Nassar, Heba A. Nasr and Abd El-Nasser A. Kobisi gratefully acknowledge the approval and support of this research study by the grant No. 7246-SAR-2017-1-8-F from Deanship of Scientific Research, Northern Border University, Arar, KSA.

\section{References}

Ash, C., Priest, F.G. and Collins, M.D. (1993) Molecular identification of rRNA group 3 Bacilli (Ash, Farrow, Wallbanks and Collins) a PCR probe test. Antonie van Leeuwenhoek, 64, 253-260.

Bloemberg, G. and Lugtenberg, V.B.J. (2001) Molecular basis of plant growth promotion and biocontrol by rhizobacteria. Curr. Opin. Plant Biol. 4, 343-350. 
Brzezinska, M.S., Jankiewicz, U., Burkowska, A. and Walczak, M. (2014) Chitinolytic microorganisms and their possible application in environmental protection. Curr. Microbiol. 68, 71-81.

Budi, S.W., van Tuinen, D., Arnould, C., Dumas-Gaudut, E., Gianinazzi- Pearson, V. and Gianinazzi, S. (2000) Hydrolytic enzyme activity of Paenibacillus sp. strain B2 and effect of antagonistic bacterium on cell wall integrity of two soil-borne pathogenic fungi. Appl. Soil Ecol. 15, 191-199.

Chandrasekaran, R., Revathi, K., Nisha, S., Kirubakaran, S.A., Sathish-Narayanan, S. and Senthil-Nathan, S. (2012) Physiological effect of chitinase purified from Bacillus subtilis against the tobacco cutworm Spodopteralitura Fab. Pesticide Biochem. Phys. 104, 65-71.

Chang, W.T., Chen, C.S. and Wang, S.L. (2003) An antifungal chitinase produced by Bacillus cereus with shrimp and crab shell powder as a carbon source. Curr. Microbiol. 47, 102-108.

Chet, I., Ordentlich, A., Shapira, R. and Oppenheim, A. (1990) Mechanisms of biocontrol of soil-borne plant pathogens by Rhizobacteria. Plant Soil, 129, 85-92.

Dahiya, N., Tewari, R. and Hoondal, G.S. (2006) Biotechnological aspects of chitinolytic enzymes: A review. Appl. Microbiol. Biotechnol. 71, 773-782.

Dai, D.H., Hu, W.L., Huang, G.R. and Li, W. (2011) Purification and characterization of a novel extracellular chitinase from thermophilic Bacillus sp. Hu1. Afr. J. Biotechnol. 10, 2476-2485.

Faramarzi, M.A., Fazeli, M., Yazdi, M.T., Adrangi, S., Ahmadi, K.J.A., Tasharrofi, N. and Mohseni, F.A. (2009) Optimization of cultural conditions for production of chitinase by a soil isolate of Massilia timonae. Biogeosci. 8, 93-99.

Flach, J., Pilet, P.E. and Jollès, P. (1992) What's new in chitinase research? Experientia, 48, 701-716.

Fu, X., Yan, Q., Wang, J., Yang, S. and Jiang, Z. (2016) Purification and biochemical characterization of novel acidic chitinase from Paenicibacillus barengoltzii. Int. J. Biol. Macromol. 91, 973-979.

Fundagül, E., Muharrem, C. and Barcin, K. (2009) Identification of Bacillus species isolated from ropey breads both with classical methods and API identification kits. Akdeniz Univ. Facu. Agric. J. 22, 201-210.

García-Fraga, B., da-Silva, A.F., López-Seijas, J. and Sieiro, C. (2015) A novel family 19 chitinase from the marine-derived Pseudoalteromonas tunicata CCUG 44952T: Heterologous expression, characterization and antifungal activity. Biochem. Eng. J. 93, 84-93.

Geetha, K., Venkatesham, E., Hindumathi, A. and Bhadraiah, B. (2014) Isolation, screening and characterization of plant growth promoting bacteria and their effect on Vigna Radita (L.) R. Wilczek. Int. J. Curr. Microbiol. App. Sci. 3, 799-809.

Gothwal, R.K., Nigam, V.K., Mohan, M.K., Sasmal, D. and Ghosh, P. (2007) Extraction of bulk DNA from Thar Desert soils for optimization of PCR-DGGE based microbial community analysis. Electron $J$. Biotechnol. 10, 400-408.

Hegedus, D., Erlandson, M., Gillott, C. and Toprak, U. (2009) New insights into peritrophic matrix synthesis, architecture, and function. Annu. Rev. Entomol. 54, 285-302.

Holt, J.G., Krieg, N.R., Sneath, P.H.A., Staley, J.T. and Williams, S.T. (1994) "Bergey's Manual of Determinative Bacteriology". $9^{\text {th }}$ ed., pp.559-565. Williams and Wilkins, USA.

Hui, D.D., Wei, L., Lian, W.H.U. and Ying, S.A.X. (2011) Effect of medium composition on the synthesis of chitinase and chitin deacetylase from thermophilic Paenibacillus sp. Hu1. Procedia Environ. Sci. 8, 620-628.

Itoh, T., Sugimoto, I. and Hibi, T., et al. (2014) Overexpression, purification, and characterization of Paenibacillus cell surface-expressed chitinase ChiW with two catalytic domains. Biosci. Biotechnol. Biochem. 78, 624-634.

Jeraj, N., Kunic, B., Lenasi, H. and Breskvar, K. (2006) Purification and molecular characterization of chitin deacetylase from Rhizopus nigricans. Enzyme Microbial. Technol. 39, 1294-1299.

Kim, H.S., Timmis, K.N. and Golyshin, P.N. (2007) Characterization of a chitinolytic enzyme from Serratia sp. KCK isolated from kimchi juice. Appl. Microbiol. Biotechnol. 75, 1275-1283. 
Kim, Y.C., Jung, H., Kim, K.Y. and Park, S.K. (2008) An effective biocontrol bioformulations against Phytophthora blight of pepper using growth mixtures of combined chitinolytic bacteria under different field conditions. Eur. J. Plant Pathol. 120, 373-382.

Kim, Y.C., Lee, J.H., Bae, Y.S., Sohn, B.K. and Park, S.K. (2010) Development of effective environmentallyfriendly apporaches to control Alternaria blight and anthracnose diseases of Korean ginseng. Eur. J. Plant Pathol. 127, 443-450.

Kim, Y.C., Leveau, J., McSpadden, Gardener B.B., Pierson, E.A., Pierson, L.S. and Ryu, C.M. (2011) The multifactorial basis for plant health promotion by plant-associated bacteria. Appl. Environ. Microbiol. 77, 1548-1555.

Kunamneni, A., Permaul, K. and Singh, S. (2005) Amylase production in solid state fermentation by the thermophilic fungus Thermomyces lanuginosus. J. Biosci. Bioeng. 100, 168-171.

Kuzu, S.B., Guvenmez, H.K. and Denizci, A.A. (2012) Production of a thermostable and alkaline chitinase by Bacillus thuringiensis subsp. kurstaki strain HBK-51. Biotechnol. Res. Int. 2012, 1-6.

Lee, K.Y., Heo, K.R., Choi, K.H., Kong, H.G., Nam, J.S., Yi, Y.B., Park, S.H., Lee, S.W. and Moon, B.J. (2009) Characterization of a chitinase gene exhibiting antifungal activity from a biocontrol bacterium Bacillus licheniformis N1. Plant Pathol. J. 25, 344-351.

Logan, N.A. and Berkeley, R.C.W. (1984) Identification of Bacillus strains using the API system. J. Gen. Microbiol. 130, 1871-1882.

Lorito, M., Hayes, C.K., Di Pietro, A., Woo, S.L. and Harman, G.E. (1994) Purification, characterization, and synergistic activity of a glucan $1,3-\beta$-glucosidase and an N-acetyl- $\beta$ - glucosaminidase from Trichoderma harzianum. Phytopathol. 84, 398-405.

Manucharova, N.A., Vlasenko, A.N., Menko, E.V. and Zvyagintsev, D.G. (2011) Specificity of the chitinolytic microbial complex of soils incubated at different temperatures. Microbiol. 80, 205-215.

Massol-Deya, A.A., Odelson, D.A., Hickey, R.F. and Tiedje, J.M. (1995) Bacterial community fingerprinting of amplified $16 \mathrm{~S}$ and $16-23 \mathrm{~S}$ ribosomal DNA gene sequences and restriction endonuclease analysis (ARDRA). In: "Molecular Microbial Ecology Mannul", Akkermans, A.D.L., van Elsas, J.D. and de Bruijn, F.J. (Ed.), pp 1-8. Kluwer, Dordrecht.

Natalija, A. and Dzoko, K. (2018) In vitro potential of Paenibacillus alvei DZ-3 as a biocontrol agent against several phytopathogenic fungi. Biologija, 64, 65-72.

Nelson, N.A. (1944) A photometric adaptation of the somogyi method for the determination of glucose. J. Biol. Chem. 153, 375-380.

Pachapur, V.L., Guemiza, K., Rouissi, T., Sarma, S.J. and Brar, S.K. (2016) Novel biological and chemical methods of chitin extraction from crustacean waste using saline water. J. Chem. Technol. Biotechnol. 91, 2331-2339.

Patel, B., Gohel, V. and Raol, B. (2007) Statistical optimization of medium components for chitinase production by Paenibacillus sabinae strain JD2. Ann. Microbiol. 57, 589-597.

Reyes-Ramirez, A., Escudero-Abaraca, B.I., AguilarUscanga, G., Hayward-Jones, P.M. and BarbozaCorona, J.E. (2004) Antifungal activity of Bacillus thuringiensis chitinase and its potential for the biocontrol of phytopathogenic fungi in soybean seeds. J. Food Sci. 69, M131-M134.

Ruth, C., Steven, Y., Pauline, C., Veronika, I.S. and Tjandra, P. (2016) Production and characterization of chitinases from thermophilic bacteria isolated from Prataan Hot Spring, East Java. J. Math. Fund. Sci. 48, 149-163.

Savita, M., Raj, K.G., Jyoti, S., Krishna, M., Purnendu, G. (2013) Chitinase production by a newly isolated thermotolerant Paenibacillus sp. BISR-047. Annals Microbiol. 64, 787-797.

Sheng, J.X., Sae, J.H., Woobong, C. and Byung, S.K. (2014) Antifungal activity of Paenibacillus kribbensis strain T-9 isolated from soils against several plant pathogenic fungi. Plant Pathol. J. 30, 102-108.

Singh, A.K. (2010). Optimization of culture conditions for thermostable chitinase production by Paenibacillus sp. D1. Afr. J. Microbiol. Res. 4, 2291-2298. 
Sneath, P.H.A. (1984) Endospore forming Grampositive rods and cocci. In: "Bergey's Manual of Systematic Bacteriology", Sneath, P.H.A (Ed.), pp. 1104-1139, Vol. 2. Williams \& Wilkins. Baltimore.

Tamura, K., Dudley, J., Nei, M. and Kumar, S. (2007) MEGA4: Molecular evolutionary genetics analysis (mega) software version 4.0. Mol. Biol. Evol. 24, 1596-1599.

Ueda, J. and Kurosawa, N. (2015) Characterization of an extracellular thermophilic chitinase from Paenibacillus thermoaerophilus strain TC22$2 \mathrm{~b}$ isolated from compost. World J. Microbiol. Biotechnol. 31, 135-143.

Ulrike, E., Rogall, T., Blocker, H., Emde, M. and Bottger, E.C. (1989) Isolation and direct complete nucleotide determination of entire genes. Characterization of a gene coding for $16 \mathrm{~S}$ ribosomal RNA. Nucl. Acid Res. 17, 7843-7853.

Vyas, P. and Deshpande, M.V. (1989) Chitinase production by Myrothecium verrucaria and its significance for fungal mycelia degradation. J. Gen. Appl. Microbiol. 35, 343-350.

Wadetwar, R.N. and Patil, A.T. (2013) Isolation and characterization of bioactive actinomycetes from soil in and around Nagpur. Int. J. Pharm. Sci. Res. 4, 1428-1433.
Williams, S.T., Sharpe, M.E. and Holt, J.G. (1989) "Bergey's Manual of Systematic Bacteriology" Vol. 4, 1813p.

Xiaoxiao, G., Pei, X., Minhua, Z. and Wenyong, L. (2017) Purification and characterization of alkaline chitinase from Paenibacillus pasadenensis CS0611. Chinese J. Catal. 38, 665-672.

Yan, Q. and Fong, S.S. (2015) Bacterial chitinase: Nature and perspectives for sustainable bioproduction. Bioresour. Bioprocess, 2, 31.

Yong, H.K., Seur, K.P., Jin, Y.H. and Young, C.K. (2017) Purification and characterization of a major extracellular chitinase from a biocontrol bacterium, Paenibacillus elgii HOA73. Plant Pathol. J. 33, 318-328.

Yuli, P.E., Suhartono, M.T.Y., Rukayadi, Y., Hwang, J.K. and Pyun, Y.R. (2004) Characteristic of thermostable chitinase enzymes from the Indonesian Bacillus sp. 13.26. Enzyme Microb. Technol. 35, 147-153.

Zarei, M., Aminzadeh, S., Ghoroghi, A., Motalebi, A.A., Alikhajeh, J. and Daliri, M. (2012) Chitinase isolated from water and soil bacteria in shrimp farming ponds. Iranian J. Fish Sci. 11, 911-925.

(Received 4/8/2018; accepted 23/10/2018) 


\section{فعالية بكتيريا البينباسيلليس نوع ان بي آر10- المحبة للحرارة والمعزولة من التربة كعامل تحكم حيوي محلل للكيتين}

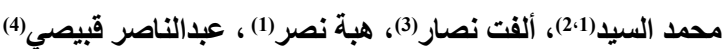

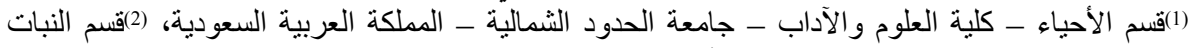

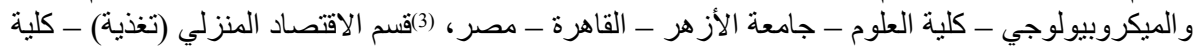

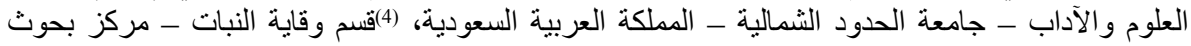

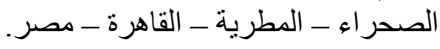

حظيت انزيمات الكيتينيز الميكروبية باهتمام متز ايد بسبب نطاقها الو اسع من تطبيقات التقنية الحيوية خاصة

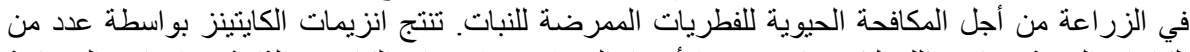

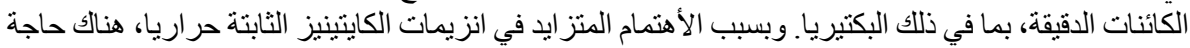

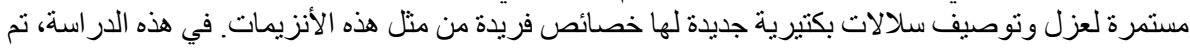

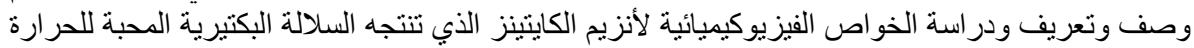

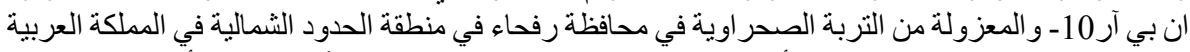

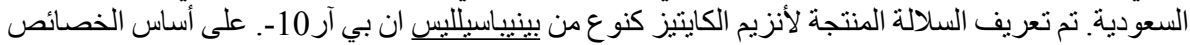

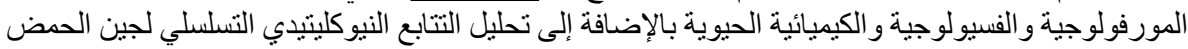

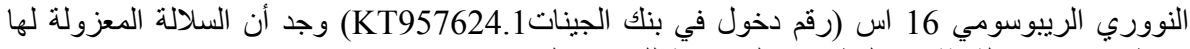

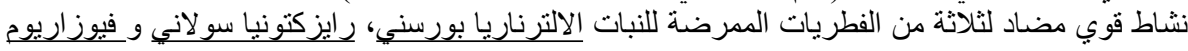

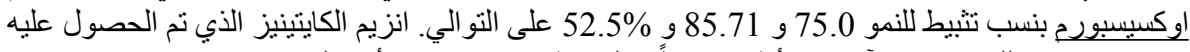

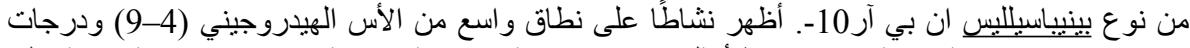

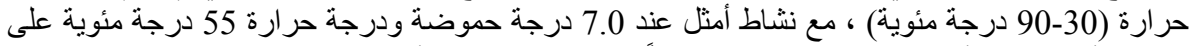

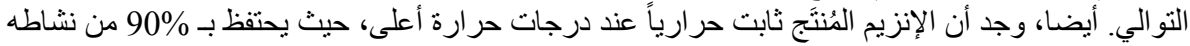

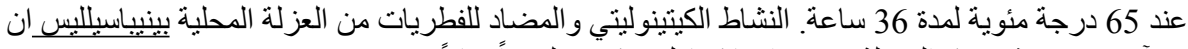
بي آر10- ، ترشح هذه السلالة لاستخدامها كعامل تحكم بيولوجياً فعالاً. 